artelogie

\section{Artelogie}

Recherche sur les arts, le patrimoine et la littérature de l'Amérique latine

$12 \mid 2018$

Idiosyncrasie de l'indigénisme en Amérique latine.

Pluralité des sources et des appropriations extra-

latino-américaines

\title{
Claudia Andujar e Marcello Tassara: O transe yanomami na fotografia e no cinema
}

Ana Carolina Albuquerque de Moraes

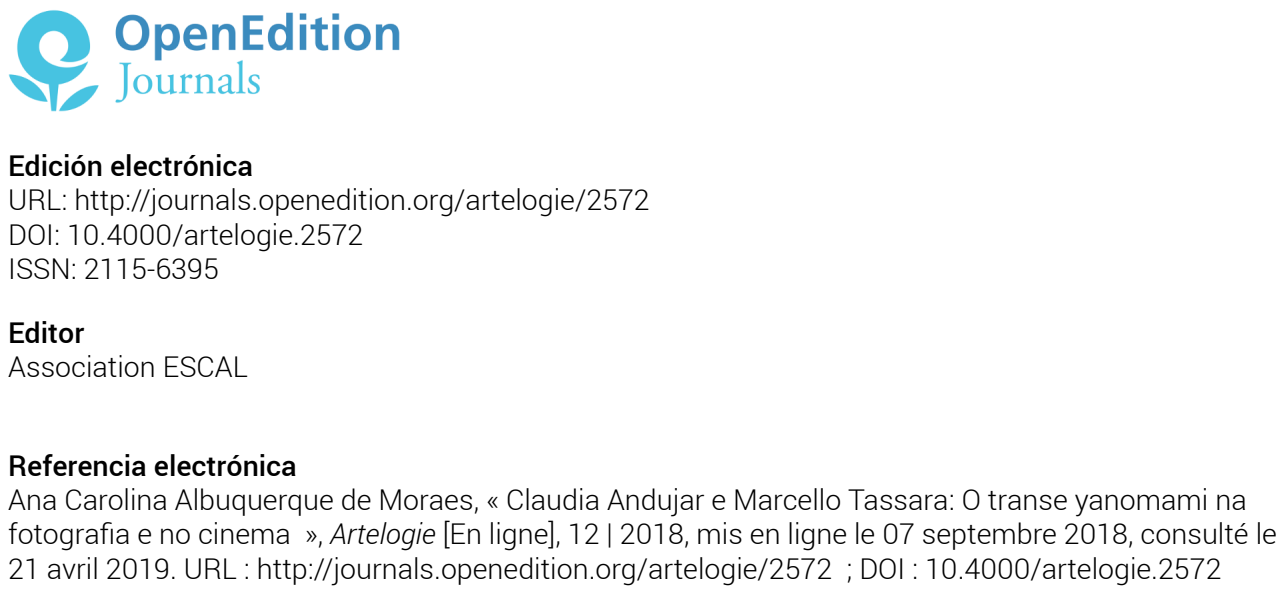

Este documento fue generado automáticamente el 21 avril 2019.

Association ESCAL 


\title{
Claudia Andujar e Marcello Tassara: O transe yanomami na fotografia e no cinema
}

\author{
Ana Carolina Albuquerque de Moraes
}

1 Este artigo visa a refletir sobre a apresentação de aspectos do transe alucinógeno entre indivíduos da tribo Yanomami na fotografia e no cinema. Selecionamos para análise duas imagens da fotógrafa Claudia Andujar, pertencentes à série Sonhos (1974-2003), e um trecho do fotofilme ${ }^{1}$ Povo da Lua, Povo do Sangue (1985), do diretor Marcello Tassara, de modo a discutir recursos por meio dos quais a fotografia e o cinema, meios originalmente marcados pelo amparo fotoquímico na realidade material, incumbem-se da tarefa de abordar conteúdos tão insólitos e imateriais quanto as sensações e visões decorrentes do consumo de alucinógenos em rituais indígenas. As fotografias e o filme em questão configuram-se como produções analógicas, de modo que a conhecida noção de "imagemtraço", no que concerne ao processo de construção das obras, faz-se pertinente em ambos os casos ${ }^{2}$.

2 O fio condutor deste texto, conforme assinalado, é o estado de transe alcançado por indivíduos (do sexo masculino) da tribo Yanomami ao inalarem yãkoana, pó obtido a partir do aquecimento de tiras da casca da árvore yãkoana hi. O depoimento do xamã yanomami Davi Kopenawa no livro A queda do céu (KOPENAWA; ALBERT, 2015), detendo-se pormenorizadamente em suas experiências de aspiração da yãkoana (obrigatórias para tornar-se xamã) e nas sensações e visões subsequentes ao consumo da substância, fornecerá respaldo ao processo de construção de significados a partir das fotografias e do fotofilme escolhidos.

\section{Sonhos}

Vivendo por longas temporadas na Amazônia, junto aos Yanomami, na década de 1970, a fotógrafa suíça naturalizada brasileira Claudia Andujar desenvolve, dentre outros interesses, grande atração pelo universo mitológico da tribo. Esse interesse dá origem a 
algumas séries fotográficas, que fazem parte do enorme arquivo Yanomami construído pela artista, com milhares de negativos.

4 Dentre as séries dedicadas ao tema, Sonhos (1974-2003) é idealizada, segundo Brandão e Machado, para integrar uma exposição na Fundação Cartier, em Paris, a convite do curador Hervé Chandes (BRANDÃO; MACHADO, In: ANDUJAR, 2005, p.174). A exposição a que os autores se referem é Yanomami, l'esprit de la forêt, em cartaz naquela fundação entre maio e outubro de 2003. Para realizar a série, Claudia debruça-se sobre seu próprio arquivo de imagens em busca de negativos e cópias que, retrabalhados, possam gerar imagens de outra natureza. Em Sonhos, portanto, os referentes das fotografias são outras fotografias da própria artista, estas últimas realizadas in loco, quando de sua permanência na Amazônia.

50 processo por meio do qual Claudia intervém sobre as imagens de seu arquivo é explicado por Paulo Herkenhoff: "consiste em tomar as cópias das suas fotografias em cores, refazê-las em preto e branco, retrabalhar em novo colorido com projeção de luz e, por fim, refotografar". (HERKENHOFF, In: ANDUJAR, Op. cit., p.235). As novas imagens ainda se remetem aos Yanomami em seu habitat natural, mas também, e cada vez mais, parecem remeter-se a elas próprias enquanto imagens. Parecem amplificar a percepção de sua materialidade, de seus artifícios formais, de seu caráter de construção ficcional a partir de dados da realidade exterior.

6 Tal caráter de construção ficcional, contudo, que salta aos nossos olhos de "homem branco" diante da observação dessas imagens, parece não reverberar no olhar que os próprios Yanomami lhes conferem. Para eles, ao que parece, aspectos muito conhecidos de seu universo mitológico, tomados como verdade incontestável, estão ali claramente representados. A esse respeito, é elucidativo um depoimento da própria fotógrafa concedido em entrevista às pesquisadoras Ana Maria Mauad e Silvana Louzada -, que aponta para a relação entre as imagens de Sonhos e o xamanismo yanomami:

0 trabalho cresceu conforme eu conheci melhor os Yanomami e a espiritualidade deles. É isso que eu posso dizer. Por exemplo, a série de superposições nasceram (sic ) por causa disso. Não é que eu vi outras superposições no trabalho de outras pessoas. As superposições que eu chamo de sonhos, sonhos, são os sonhos dos xamãs. Eles chamam isso de sonhos, de viagens. Eles dão esse nome para isso, não as minhas fotos, o estado de ser deles. Isso acontece quando eles entram em contato com os espíritos. (...) Eu sempre faço questão de colocar a questão da luminosidade, porque faz parte das crenças deles. (...) Eu diria, eu uso a tecnologia nossa, ocidental, isso sim. Mas tentando manipular as coisas com o que eu conheço da tecnologia ocidental. Mas entrando no universo deles. (...) Mas, o que me dá uma certa satisfação é que quando eu mostro esse trabalho aos Yanomami eles percebem isso. Eles fazem o que faziam com os desenhos ${ }^{3}$, ele vê essa imagem com toda essa invasão de luz e ele começa a contar a sua história. Um dia eu tinha esse trabalho Sonhos na Galeria Vermelho exposto e o Davi estava lá, estava em São Paulo e eu levei ele lá. Ele começou a falar, explicar o que eram aquelas fotos para mim, para quem estava lá. Eu estava lá, tinha umas pessoas da galeria e ele falou: 'agora eu vou explicar para vocês o que vocês estão vendo'. As pessoas ficaram com a boca aberta: 'mas como? Quem tem que explicar isso é a Claudia, como que você sabe'. 'Ah, porque eu sei, eu sei mais do que ela'. Ele não falou isso. Mas ele falou: 'Eu sei o que é isso'. Claro, não tenho dúvida, eu não sei tudo. De jeito nenhum. Eu tentei enxergar o que eu entendi. (ANDUJAR, apud MAUAD, 2012, p.139).

No texto acima, Claudia não esconde sua satisfação ao relatar que, confrontado com as imagens de Sonhos, Davi Kopenawa, influente xamã e defensor da causa yanomami, ter-seia sentido genuinamente impelido a explicar o que ali estava apresentado, sugerindo uma 
profunda familiaridade entre observador e obra. Desse modo, a artista acredita não sobrepor sua própria visão de mundo àquela do povo representado, mas atuar como uma espécie de mediadora que transforma em imagens aquilo que espontaneamente lhe chega do outro.

8 Na década de 1980, Kopenawa solicitou ao amigo etnólogo Bruce Albert ${ }^{4}$ que escrevesse um livro, levando suas palavras para muito além da floresta, na esperança de que os brancos, ao lê-las, vissem minimizada sua voracidade de conquistar suas terras. Em suas pesquisas in loco sobre o universo yanomami, Albert costumava passar longas temporadas na casa comunitária em que Davi vivia, aos pés de um maciço rochoso chamado pelos indígenas de Watoriki, a "Montanha do Vento". A partir da duradoura relação de amizade e confiança construída, o etnólogo coletou do xamã "um conjunto de falas, narrativas e conversas, gravadas em yanomami, em geral sem roteiro, ao longo de mais de dez anos, a respeito de sua vida, de seu saber xamânico e de sua experiência do mundo dos brancos". (ALBERT, In: KOPENAWA; ALBERT, 2015, p.49). Da organização dessas falas por Albert, buscando torná-las acessíveis a um público amplo, e de sua tradução para o francês, e em seguida para o português, surgiu o já citado livro A queda do céu, que, trazendo com vigor e fluência as ideias de Kopenawa, mediadas por seu amigo "branco", enriquecerão as reflexões a seguir.

9 Em Êxtase [Fig. 1], a imagem de um indivíduo do sexo masculino deitado de costas, com os olhos fechados e os braços estendidos para cima, funde-se, pelo recurso da transparência, à imagem de uma grande montanha rochosa ao fundo, que ocupa quase toda a extensão da obra. Imaginamos tratar-se de um índio em virtude de algumas características fisionômicas, sobretudo os olhos lateralmente alongados, e do conhecimento sobre o trabalho de Claudia com a tribo Yanomami, embora nada na imagem nos remeta aos estereótipos indígenas comumente difundidos (tangas, cocares, etc.). A matéria física de que é feita a montanha parece constituir também a matéria física de que é feito o corpo, gerando uma tal simbiose homem-terra em que nenhum elemento parece dispor de existência autônoma.

10 No livro, Kopenawa insiste em que, para tornar-se xamã, é preciso "morrer" sob o efeito da yãkoana, inúmeras vezes e com persistência, até conseguir, passados vários dias, entrar em contato com os xapiri (espécies de espíritos habitantes da floresta), ouvindo primeiro seus cantos, depois vendo suas imagens em sonhos. O poder da yãkoana é tamanho que "quando a pessoa não o conhece, ela é logo derrubada com muita força e despenca no chão". (KOPENAWA; ALBERT, Op. cit., p.136-137). A “morte" aqui é metáfora para a renúncia ao estado de vigília, para a perda de consciência que permite ao indivíduo ingressar em estado de sonho, no qual surgem visões atribuídas a um mundo sobrenatural. Nesse estado, enquanto o corpo do xamã permaneceria prostrado, inerte, sua imagem seria levada pelos xapiri para muito longe, voando por distâncias incalculáveis, "em todas as direções da floresta, do céu e debaixo da terra". (Ibid., p.137). Assim lhe seria revelado "o desenho da floresta", para que pudesse protegê-la, bem como "a aproximação das fumaças da epidemia, dos seres maléficos da floresta ou dos espíritos do vendaval". (Ibid., p.142).

11 Sobre a noção yanomami de xapiripë - sendo pë o elemento indicativo do plural -, Eduardo Viveiros de Castro esclarece:

A palavra designa o utupë, imagem, princípio vital, interioridade verdadeira ou essência (...) dos animais e outros seres da floresta, e ao mesmo tempo as imagens 
imortais de uma primeira humanidade arcaica, composta de Yanomami com nomes animais que se transformaram nos animais da atualidade.

Mas o termo xapiripë se refere também aos xamãs humanos, e a expressão 'tornar-se xamã' é sinônima de 'tornar-se espírito', xapiri-pru. Os xamãs se concebem como de mesma natureza que os espíritos auxiliares que eles trazem à terra em seu transe alucinógeno. (VIVEIROS DE CASTRO, 2006, p.321)

12 Na crença yanomami, em um certo passado primordial, os animais possuiriam forma humana. Ao virarem caça, seus descendentes teriam assumido os corpos animais que conhecemos hoje, porém seus espíritos - xapiri - continuariam existindo eternamente, preservando suas características humanoides. Esses espíritos, invisíveis aos olhos comuns, seriam inumeráveis: além de cada animal possuir sua própria imagem ancestral, outros seres da floresta - O Raio, o Trovão, a Chuva, a Noite, etc. - também seriam providos de respectivas imagens xapiri. Tais imagens constituiriam a verdadeira essência de cada ser florestal, e apenas o xamã, ao inalar reiteradamente a yãkoana, estaria habilitado, em suas visões alucinógenas, a entrar em contato com elas, obtendo assim o conhecimento verdadeiro sobre os vários aspectos da floresta. Os próprios xamãs - xapiri também -, assumiriam, durante o transe, qualidades semelhantes às dos espíritos, tornando-se ao mesmo tempo humanos e não-humanos, vivendo em estado polimorfo. Assim, como Viveiros de Castro cuidadosamente explica, a noção de xapiri designa menos uma classe ou categoria fixa de seres que "uma região ou momento de indiscernibilidade entre o humano e o não-humano", em que seres poderiam metamorfosear-se continuamente, assumindo identidades híbridas, numa "multiplicidade virtual intensiva" (Ibid., p.321). Remetendo-se a um passado absoluto em que não haveria diferenciação entre espécies, sequer entre humano e não-humano, "os espíritos são o testemunho de que nem todas as virtualidades foram atualizadas e que o turbulento fluxo mítico continua a rugir surdamente por debaixo das descontinuidades aparentes entre tipos e espécies" (Ibid., p.324).

13 Na imagem analisada, a "morte" sob o efeito da yãkoana é sugerida pela posição do corpo prostrado, "entregue" - e pela expressão serena da face, os olhos fechados e a boca entreaberta como que a dormir profundamente. A ideia de uma "imagem" que voa, um espectro e não um corpo sólido, é sugerida pela fusão da textura da pele com a da rocha, através do recurso da transparência, e pela imprecisão dos contornos da figura humana. Apesar da fusão, o espectro humano sobressai-se na paisagem, sobretudo do torso para cima, tendo seu volume sutilmente realçado por jogos de luz e sombra, que o trazem para o primeiro plano. Esse recurso nos dá a impressão de que a fluida figura está "em cima" da montanha, voando sobre ela, o que aponta para a ideia de um voo xamânico por alturas e distâncias impensáveis, desbravando regiões inacessíveis ao ser humano comum, como relata Kopenawa. $O$ agigantamento das dimensões do corpo em relação à montanha, atravessando-a transversalmente em toda sua extensão visível, sugere ainda o domínio do xamã sobre os fenômenos da natureza, o poder sobrenatural daquele indivíduo sobre o meio, o que lhe credenciaria a proteger sua tribo contra infortúnios futuros, objetivo último do papel social para o qual fora iniciado.

14 O fato de que a textura da pele funde-se com a da montanha rochosa também aponta para outras camadas de significação. Para os Yanomami, as montanhas seriam "casas de espíritos; casas de ancestrais" (KOPENAWA; ALBERT, Op. cit., p.118). Numerosíssimos, os espíritos demandariam casas muito grandes, e assim as montanhas teriam sido criadas por Omama, o demiurgo yanomami, para abrigarem essas entidades. Toda a longa e dolorosa preparação ritualística de um aspirante a xamã, inalando incansavelmente o pó 
da yãkoana e privando-se temporariamente de determinados alimentos (carne, água) e hábitos (banho, sexo), visaria a promover a purificação de suas entranhas para receber os xapiri, sempre muito temperamentais e exigentes quanto às virtudes de seus anfitriões. Tratar-se-ia de um longo período de sedução, em que o xamã precisaria provar-lhes suas sinceras intenções, até que eles decidissem descer de suas casas, no topo das montanhas, e vir-lhe fazer sua dança de apresentação. Quanto mais experiente o xamã, mais espíritos sairiam de suas casas para vir até ele cantar e dançar. (Ibid.). Assim, a figura humana sobreposta à montanha, com ela fundindo-se pelo recurso da transparência, poderia evocar também aquela zona ancestral de "indiscernibilidade entre o humano e o nãohumano" de que fala Viveiros de Castro, zona revivida pelo ritual xamânico: ao esforçarse com todo o afinco para ver e ouvir os xapiri, o xamã tornar-se-ia também xapiri (representados na imagem por sua casa, a montanha), retomando aquele passado absoluto em que os seres podiam metamorfosear-se sem assumir identidades fixas. “(...) é ao 'morrer' sob o efeito da droga alucinógena yãkoana que os xamãs são capazes não apenas de ver os espíritos, mas de ver como os espíritos". (VIVEIROS DE CASTRO, Op. cit., p.329-330).

15 Em Floresta Amazônica, Pará [Fig. 2], uma cabeça humana surge na porção central superior da imagem, mesclando-se, pelo recurso da transparência, a troncos, galhos e folhagens de uma vegetação farta. Duas imprecisas imagens de braços com pulseiras, cuja solidez também é embotada pela fusão com o ambiente, posicionam-se acima e abaixo da cabeça e ainda uma terceira pulseira, mais imprecisa que as outras, é vislumbrada à direita. Destaca-se o braço de cima, que surge à esquerda e culmina no centro, onde a mão pousa sobre o topo da cabeça. Atravessando toda a imagem, e fundindo-se aos elementos humanos, vemos árvores frondosas de uma exuberante paisagem. Linhas diagonais de troncos e braços levam o olhar em direção à cabeça, que, ainda pelo local em que está situada e pela zona de luz na testa, torna-se o principal ponto focal da imagem. Mais uma vez, trajes e ornamentos tipicamente reconhecidos como indígenas não se fazem presentes na cena.

16 Iniciado no xamanismo pelo sogro, Kopenawa relata em detalhes suas primeiras experiências com a yãkoana, descritas como comuns a todo xamã iniciante. Afirma ter sentido dores intensas, sobretudo nas costas e na nuca, o que atribui a golpes impiedosos dos xapiri com suas armas, compostas de grandes lâminas de metal. Após o golpearem com toda a força, os xapiri teriam trinchado a "imagem" de seu corpo em várias partes (tronco, pernas, pescoço, cabeça, língua, dentes, vísceras, etc.), levando-as consigo para lugares muito longínquos, onde iriam purificá-las, consertá-las, aprimorá-las, embelezálas, de modo a torná-las dignas de um xamã - o "pai dos xapiri" -, cujas partes do corpo deveriam ser reconstruídas à imagem e semelhança desses espíritos.

Depois de me cortarem, os xapiri fugiram depressa com as partes de meu corpo que tinham acabado de trinchar, para longe da nossa floresta, muito além da terra dos brancos. Eu tinha perdido a consciência e foi minha imagem que eles desmembraram, enquanto minha pele permanecia no chão. Voaram para um lado com meu torso e para o outro com meu ventre e minhas pernas. Carregaram minha cabeça numa direção, e minha língua em outra. (KOPENAWA; ALBERT, Op. cit., p.154).

17 Com base no relato de Kopenawa, é possível compreender a obra em questão como a "imagem" da cabeça do xamã sendo levada pelas mãos dos espíritos, após a "imagem" de seu corpo ter sido trinchada. $\mathrm{O}$ foco de luz sobre a testa poderia aludir ao processo de purificação e ampliação das faculdades mentais pelo qual a cabeça passaria durante a 
viagem. Tal ideia de renovação e aprimoramento das capacidades intelectuais e sensórias do indivíduo submetido a essa espécie de "cirurgia espiritual" aparece no desfecho do episódio contado por Kopenawa:

(...) assim que eles [os xapiri] recompuseram as partes de meu corpo, meu pensamento começou a desabrochar de novo. Senti-me acordar, imerso no perfume forte da tinta de urucum com que me tinham pintado e na fragrância de suas plantas mágicas yaro xi e aroari. (Ibid., p.155).

18 A fala de Kopenawa refere-se a uma "imagem" do corpo que dele se desvincula. Como parte da transformação de um homem comum em xamã, os xapiri apossar-se-iam da "imagem" de seu corpo, desmembrá-la-iam em muitas partes, voariam com elas para distâncias longínquas onde as remodelariam, aperfeiçoando-as, e, por fim, "encaixá-lasiam" novamente, agora aprimoradas, de modo a constituírem uma nova "imagem" do corpo. Ao longo de todo esse processo, enquanto a "imagem" do corpo seria inteiramente modificada, assumindo nova configuração, o corpo em si permaneceria deitado, inerte, formalmente idêntico ao que era no momento anterior ao transe. Ocorreria, assim, uma dissociação entre o corpo e sua imagem, em que esta ganharia poderes sobre-humanos, enquanto o primeiro preservaria sua humanidade imanente.

Essas reflexões apontam para a ideia de que a noção de imagem aqui evocada difere bastante daquela a que estamos acostumados: algo visível, para ser visto. Como bem explica Viveiros de Castro (Op. cit., p.325), a noção de imagem para os Yanomami está intimamente ligada à de xapiri: estes são imagens, porém, por um lado, não se parecem com os corpos materiais a que se referem e, por outro, não são visíveis ao olho humano comum. São, portanto, imagens não-icônicas e não-visíveis. Conforme já mencionado, as imagens xapiri dos ancestrais animais seriam antropomorfas, pois, segundo a crença yanomami, os animais que hoje conhecemos teriam possuído forma humana no princípio dos tempos. Embora esses antepassados tenham virado caça e, posteriormente, nascido em corpos animais, seus espíritos preservariam as formas humanas, eternamente alusivas ao passado mítico. Tais imagens, portanto, não seriam investidas de iconicidade: sua relação com o referente seria, antes, indicial, pois carregariam consigo uma gama de afetos característicos daquele ser, sem, no entanto, parecer-se com ele. Simultaneamente, o exercício da visão comum não serviria à visualização dessas imagens: seria necessário o acionamento de um outro tipo de visão, com os olhos fechados, após a "morte" sob o efeito da yãkoana. Nas palavras do autor:

(...) o que define uma 'imagem' é sua visibilidade eminente: uma imagem é algopara-ser-visto, é o correlativo objetivo necessário de um olhar, uma exterioridade que se põe como alvo da mirada intencional; mas os xapiripë são imagens interiores, 'moldes internos', inacessíveis ao exercício empírico da visão. Eles são o objeto, poder-se-ia dizer, de um exercício superior ou transcendental desta faculdade: imagens que seriam então como a condição daquilo de que são imagem; imagens ativas, índices que nos interpretam antes que os interpretemos; enigmáticas imagens que devem nos ver para que possamos vê-las. (Ibid., p.325)

As imagens são, assim, dotadas de tamanho poder no modo de pensar yanomami que consistem na própria condição de existência dos seres a que se referem, existindo antes e depois deles, suplantando com sua imortalidade a finitude dos corpos materiais. Entre os Yanomami, como em muitas culturas ameríndias, o verdadeiro conhecimento seria obtido por meio do acesso às imagens primordiais, possibilitado por "visões" interiores surgidas em sonhos, estimulados por alucinógenos, que funcionariam como espécies de "próteses visuais" (Ibid., p.330). Disso depreende-se a decisiva ênfase desses povos na visão como 
veículo preferencial para o conhecimento. Remetendo-se a falas de seu interlocutor, Davi Kopenawa, Bruce Albert ressalta "o antagonismo irredutível entre dois modos de conhecimento, o dos 'estrangeiros, inimigos', que tem suas raízes na escrita, e o dos Yanomami, fundamentado na visão - conhecimento xamânico". (ALBERT, In: ALBERT; RAMOS (Org.), 2002, p.248). O conhecimento obtido pelos brancos por meio de palavras seria superficial, e mesmo falso, pois fincado nos domínios das mercadorias. 0 conhecimento legítimo, relacionado à essência de cada ser florestal, apenas poderia ser acessado pelos xamãs em suas visões oníricas. (Ibid. p.248-249).

21 Retomando a discussão sobre a figura 2, poderíamos pensar que o sacrifício da decapitação só revigoraria o sujeito porque ocorreria no plano da imagem, não no físico. Justamente porque se dariam no plano simbólico, as transformações operadas no corpo seriam muito mais poderosas, assumindo tamanho, intensidade e configuração apenas possíveis em visões oníricas. No plano da imagem, seres podem ser decapitados, esquartejados, remodelados e reintegrados, podem metamorfosear-se infinitamente sem nunca desintegrar-se, podem beneficiar-se de poderes sobrenaturais. Se é certo que a imagem não altera o corpo físico, também é certo que, em culturas ameríndias, o corpo físico é revitalizado pela crença no poder da imagem.

\section{Povo da Lua, Povo do Sangue}

22 Povo da Lua, Povo do Sangue (1985) constitui-se no terceiro fotofilme realizado pelo diretor Marcello Tassara, com trinta e quatro minutos de duração. À época coordenadora da CCPY, Claudia Andujar convidou Tassara para realizar um filme cuja matéria-prima fosse constituída por fotografias de seu amplo arquivo Yanomami, além de sons captados por ela própria durante suas incursões pelas terras da tribo. Patrocinado por duas ONGs internacionais (Oxfam e Fastenopfer), o filme tinha por objetivo dar a conhecer ao público aspectos sociais e culturais do povo yanomami, denunciando as invasões destruidoras do "homem branco" sobre suas terras. Visava, em última instância, a servir de aliado na angariação da opinião pública em prol da homologação do território yanomami. (ELIAS, 2009).

23 O projeto foi apoiado pela TV Cultura, canal que cedeu sua mesa de animação para a confecção do filme e, posteriormente, exibiu-o várias vezes em sua programação, contribuindo para a notoriedade nacional da obra. Internacionalmente, Povo da Lua, Povo do Sangue foi exibido em diversos festivais pela América, Europa e Ásia, além de ter sido agraciado com o prêmio de melhor curta-metragem na edição de 1985 do Festival de Cinema Documental de Oberhausen, na Alemanha. (Ibid.)

24 Após texto introdutório em inglês, que fornece informações gerais sobre a tribo yanomami e a ameaça que esta vinha sofrendo em virtude dos interesses financeiros dos brancos sobre suas reservas, o filme apresenta sequencialmente, uma a uma, fotografias de indivíduos portando no tórax placas com inscrições numéricas - imagens que, nos anos 2000, viriam a constituir a série Marcados. ${ }^{6} \mathrm{Na}$ última fotografia desse bloco, vemos, na parte superior direita da tela, o rosto de um jovem indígena, que tem o corpo coberto por uma grande bandeira nacional, com sua inscrição positivista de "Ordem e Progresso". Esse pequeno bloco de imagens, intercaladas aos sons de um projetor analógico de slides, dá-nos, já de início, o tom do filme: a denúncia contra a introdução forçosa de signos 
(números, bandeira) de uma sociedade dita letrada e civilizada no modo de viver indígena.

O filme segue dividido em duas grandes partes. A primeira é destinada a revelar aspectos da cosmogonia, da organização hierárquica e das práticas cotidianas do povo yanomami. As fotografias de Claudia Andujar, sucedendo-se na tela, são acompanhadas por diversos tipos de sons captados in loco, alguns trechos musicais e a narração em off, realizada por uma suave voz feminina ${ }^{7}$, que surge intermitentemente para explicar determinados aspectos dos hábitos e das crenças yanomami. Os movimentos de câmera no interior das fotografias, assim como recursos de fusão, justaposição e multiplicação de imagens, põem em movimento parte do arquivo fotográfico de Claudia, conferindo ritmo à narrativa visual. A segunda parte do filme, por sua vez, foca-se sobre aspectos da chegada do "homem branco" às terras yanomami a partir da década de 1970. Os índios passam a usar roupas, recebem instrução religiosa católica, têm suas casas ocupadas por imagens da cultura de massa (cartazes com mulheres seminuas, por exemplo), contraem doenças diversas, morrem aos milhares em virtude de epidemias. 0 tom suave e didático da primeira parte do filme, que nos apresenta a riqueza do modo de vida yanomami na floresta, é substituído pelo tom melancólico da segunda, que se foca na avalanche capitalista sobre as terras e os aspectos culturais da tribo.

26 A primeira parte do filme, que dura pouco mais de dezessete minutos, culmina com a abordagem da cerimônia funerária chamada reahu, que se estende por cerca de uma semana, reunindo várias comunidades diferentes em uma única aldeia, conforme explica a narração em off. A cerimônia presencia experiências de transe decorrentes da utilização da yãkoana, inalada conjuntamente por todos os homens da aldeia no último dia de festa. Mais de quatro minutos do filme são dedicados a abordar o transe alucinógeno subsequente ao consumo da substância, o que aponta para a importância desses rituais no modo de vida yanomami. ${ }^{8}$ É esse trecho específico do filme, que trata de experiências de transe, que será analisado a seguir.

27 Incialmente, acompanhando uma imagem em que negras silhuetas contrastam com luzes intensas, ouvimos longos gritos masculinos, de uma voz excitada e trêmula, sobre um fundo sonoro em que vozes misturam-se, de modo indiscernível, no alvoroço de um encontro comunitário. Já na imagem seguinte, um dos corpos masculinos nus apresenta uma grande mancha de luz no lugar da cabeça, dando a ver um recurso técnico bastante utilizado por Claudia, que surgirá em várias fotografias mostradas nesse trecho do filme: o uso combinado de flash e longa exposição. A câmera movimenta-se por essas imagens e ouvimos os ruídos da algazarra, até que se inicia a narração em off explicando a cerimônia reahu, acompanhada por fotografias que apresentam corpos femininos e masculinos nus ou enfeitando-se para a festa. Seguem-se imagens de homens segurando uma espécie de cuia e vertendo-a sobre o nariz e a boca. A voz off explica o uso da yãkoana por xamãs ${ }^{9}$ para, entrando em contato com os espíritos, proteger a tribo de doenças e infortúnios, ao mesmo tempo em que se sucedem fotografias de rostos masculinos, provavelmente xamãs yanomami.

28 Vemos novamente imagens de um indivíduo aspirando a substância até que se inicia a abordagem do transe propriamente dito. Diante da câmera, algumas fotografias realizam um movimento circular. Elas mostram em sequência: um homem desacordado (o mesmo que, segundos antes, inalava a yãkoana); um indivíduo de pé, de costas (como que a dançar para os espíritos), cercado por manchas tremulantes de luz; e a metade inferior de um rosto, coberto por uma mão (como que a aspirar a substância), com manchas ondulantes 
de luz mais uma vez acompanhando a imprecisa figura. Simultaneamente a essas imagens, gemidos, gritos e cantos compõem a trilha sonora.

29 Relatando seu ritual de iniciação ao xamanismo, quando seu sogro o teria submetido, seguidas e diversas vezes, ao consumo da yãkoana, Kopenawa menciona a sensação de vertigem: "Primeiro, a floresta se transformou num imenso vazio que ficava rodopiando em torno de mim”. (KOPENAWA; ALBERT, Op. cit., p.146). É possível que o movimento circular das imagens diante da câmera remeta a essa sensação de tontura subsequente à inalação do pó alucinógeno. Quanto aos gemidos e gritos, o xamã explica que os primeiros contatos com a substância costumam gerar pavor e descontrole, tendo em vista a potência da droga:

No começo, quando a pessoa ainda não conhece o poder da yãkoana, não fica de pé muito tempo. Foi também o que aconteceu comigo. Sua força me fez morrer e me jogou para trás na hora. Então, rolei no chão, me contorcendo de pavor e gemendo: 'Akaaa! Akaaa!' (Ibid., p.145).

Na sequência do filme, fragmentos de rostos em transe surgem e desaparecem sutilmente na escuridão, envoltos em luzes muito baixas. A narração em off entra novamente em cena, desta vez para referir-se ao consumo da yãkoana por todos os homens da tribo no último dia da cerimônia reahu. A voz é acompanhada por fotografias de rostos e corpos em transe, no interior e ao longo das quais a câmera movimenta-se lentamente, revelando e escondendo, sucessivamente, determinados aspectos de cada imagem.

31 A narração é interrompida, e os gritos e gemidos intensificam-se sobre um fundo musical que amplifica a atmosfera de suspense. Manchas ondulantes de luz dominam progressivamente a tela, alternando-se e, por vezes, sobrepondo-se a imagens de indivíduos em transe. Tais manchas ora aparecem e desaparecem numa fração de segundo, ora desenvolvem rápidos movimentos laterais pela tela, ora alternam-se freneticamente, numa sequência que dura mais de trinta segundos [Fig. 3]. Segundo Elias, esse efeito visual é obtido pela combinação de recursos fotográficos (o já mencionado uso casado do flash e da longa exposição por Claudia) e cinematográficos (a movimentação da câmera por Tassara, gerando rastros de luz que ficam marcados na película). (ELIAS, Op. cit.).

32 A tensão crescente da narrativa justifica-se pelo fato de esses frenéticos caminhos ondulantes de luz remeterem ao modo pelo qual, na crença yanomami, os xapiri aproximam-se do indivíduo em transe. Tal imagem onírica aparece em diversas passagens do testemunho de Kopenawa, como no trecho a seguir:

A sua tropa descia dos confins do céu, carregada por milhares de trilhas reluzentes que ondulavam nos ares. Eram tão velozes quanto aviões, e produziam uma ventania poderosa. Aquela distância imensa não era nada para eles. Afluíam sem parar, inumeráveis, vindo de todas as direções, como imagens de televisão. (...)

Seus caminhos, até então quase imperceptíveis, iam ficando cada vez mais nítidos e brilhantes. Finos como teias de aranha, flutuavam cintilando nos ares e vinham se prender junto de mim, um após o outro. Assim é. Os xapiri sempre são precedidos pelas imagens de seus caminhos. (KOPENAWA; ALBERT, Op. cit., p.151).

Às luzes ondulantes, segue-se a fotografia colorida de um indivíduo em transe, com o rosto e o olhar voltados lateralmente. A câmera aproxima-se progressivamente de seu olho, com cortes intercalando planos cada vez mais fechados, até que um clarão de luz amarela invade gradativamente a tela e a domina por completo [Fig. 4]. A sequência sugere que o indivíduo vê aquele clarão. Os gritos e ruídos cessaram, e a dominante luz amarela é acompanhada apenas pelo fundo musical, em que poucas notas repetidas 
rápida e incessantemente aludem ao estado de transe e hipnose. Invasão completa de luz, sons repetidos à exaustão: a narrativa parece chegar ao clímax, o transe consuma-se em recursos audiovisuais. Durante sua iniciação xamânica, após a sensação de tontura e vertigem, Kopenawa relata ter-se deparado com uma luz ofuscante, que parecia dominar tudo à sua volta:

(...) de repente, a luz explodiu num estrondo. E tudo ficou impregnado de uma claridade ofuscante. Eu só via a terra e o céu de muito longe, semeados de penugem branca cintilante. Essas pequenas penas luminosas cobriam tudo, flutuando leves no ar. Não havia mais sombra em lugar algum. Eu via tudo de cima, de uma altura assustadora. Então compreendi que estava começando a me tornar outro de verdade. (Ibid., p.146).

Viveiros de Castro explica que a relação entre a visão dos espíritos e a percepção de luzes ofuscantes é comum entre os povos indígenas na Amazônia. O autor pondera que a experiência da intensidade luminosa pode estar associada ao consumo das drogas alucinógenas, surgindo como um de seus efeitos bioquímicos, mas ressalta, evidentemente, que tal experiência não é vivida pelo xamã como mera consequência da ingestão da droga, mas como possibilidade de acesso a uma dimensão sobrenatural que lhe revelaria o conhecimento verdadeiro sobre a floresta. Remetendo à conhecida relação entre iluminação e conhecimento, Viveiros de Castro poeticamente associa a invisibilidade dos espíritos à sua frequência luminosa intensa demais, seu "caráter supervisível". (VIVEIROS DE CASTRO, Op. cit., p. 331-332). Talvez o pensamento possa ser configurado da seguinte forma: os espíritos não podem ser assimilados como uma experiência racional, pois sua luz é intensa demais para ser visível pelos olhos da razão.

Retornando ao filme, após o intenso clarão e mais uma curta sequência de luzes piscantes, a câmera começa a desfilar pelo corpo curvado de um indivíduo deitado, os braços abertos e o semblante sereno, imerso em sono profundo. Reconhecemos a figura humana presente na obra Êxtase, na fotografia usada como matéria-prima para a fusão posterior. A câmera atravessa lentamente seu corpo e detém-se por um momento no rosto adormecido. Contrastando com a face serena dessa figura, segue-se uma sequência de imagens de rostos masculinos, também adormecidos, porém com a testa franzida e a boca em movimento, em expressões que sugerem, ao mesmo tempo, prazer e dor. Os gritos retornam sobre o fundo musical de notas repetidas. Kopenawa explica que os rapazes que não são xamãs, ao ingerirem yãkoana ao final das festas reahu, "rolam de medo na poeira, chamando as mães! Em lugar de cantos, só se ouvem deles lamentos e gemidos (...)". (KOPENAWA; ALBERT, Op. cit., p.168). Talvez seja o caso dos indivíduos retratados nessas imagens. Por sua vez, os xamãs "se esforçam sem trégua para responder aos xapiri. Os cantos dos espíritos sempre estão atrás deles, e nunca os deixam mudos". (Ibid., p.168). É possível que uma fotografia mostrada pouco depois da sequência de rostos contorcidos, e já bem perto do final do trecho analisado do filme, represente um xamã yanomami [Fig. 5]. Nela vemos frontalmente a face de um homem mais velho, cujo lado direito é iluminado enquanto o esquerdo se perde na escuridão. Sua expressão de paz e serenidade sugere longos anos de contato com a yãkoana e os espíritos, segundo reza a crença de seu povo.

36 A sequência fílmica que aborda o transe termina com a fotografia que mostra um indivíduo adormecido, deitado de lado, com a cabeça apoiada em um dos braços [Fig. 6]. Seu corpo estendido encontra-se na parte inferior da imagem, enquanto todo o restante da cena está imerso ou na escuridão ou em intensa névoa, o que não permite a contextualização do local onde a figura se encontra. $\mathrm{O}$ corpo parece flutuar na escuridão 
enevoada, o que simbolicamente pode aludir à perda da consciência e aos conteúdos etéreos das visões oníricas. $\mathrm{O}$ desaparecimento dessa fotografia na escuridão marca o fim da primeira parte do filme.

\section{Considerações finais}

37 As fotografias e o fotofilme analisados são analógicos; portanto, baseados na ligação indicial entre referente e imagem, no "traço" do real que se imprime no suporte (filme fotográfico, película cinematográfica). É curioso pensar, no entanto, que, em ambos os casos, o "traço" do real é utilizado para remeter-nos a mundos oníricos, que se afastam bastante da realidade concreta. Usa-se o "traço" do real para aludir a sensações e visões sonhadas, imaginadas, desapegadas da realidade do mundo vivido pelo corpo material.

Nas fotografias, o corpo representado é imaterial, uma "imagem" do corpo, como ressalta Kopenawa. É a "imagem" do corpo, e não o corpo em si, que voa por cima das montanhas, que é ferida, esquartejada e recomposta pelos espíritos. Para aludir a esse mundo imaterial, Claudia Andujar opera com sobreposições de imagens e refotografia. No fotofilme, manchas de luz amorfas, impressas fotoquimicamente no papel fotográfico e na película cinematográfica, são utilizadas para representar visões relativas à chegada dos espíritos para o indivíduo que está em transe. Assim, nos casos analisados neste artigo, a ligação físico-química com o real é utilizada para aludir a um mundo - aos nossos olhos irreal, sonhado, imaginado pelos yanomami em sua explicação do mundo.

Há que se levar em conta, obviamente, as diferenças culturais quanto às noções de "real" e "irreal", pois, como vimos, para os Yanomami, o mundo dos espíritos - invisível, exceto para aqueles experimentados em yãkoana - faz parte da vida social tanto quanto as águas, as árvores, os animais e os homens - o mundo visível. Para eles, todo aquele mundo oculto e sobrenatural, com o qual acreditam entrar em contato quando aspiram a droga, é bastante "real", apenas inacessível à experiência do homem comum, como podemos perceber pela vivacidade das palavras de Kopenawa ao relatar suas vivências com o pó alucinógeno. A yãkoana, portanto, em vez de possibilitar visões de um mundo irreal, funcionaria como um canal que faria a ponte entre o humano e o não-humano, enquanto duas realidades coexistentes e profundamente interligadas, tal como naquele decisivo passado absoluto. 


\section{Figuras}

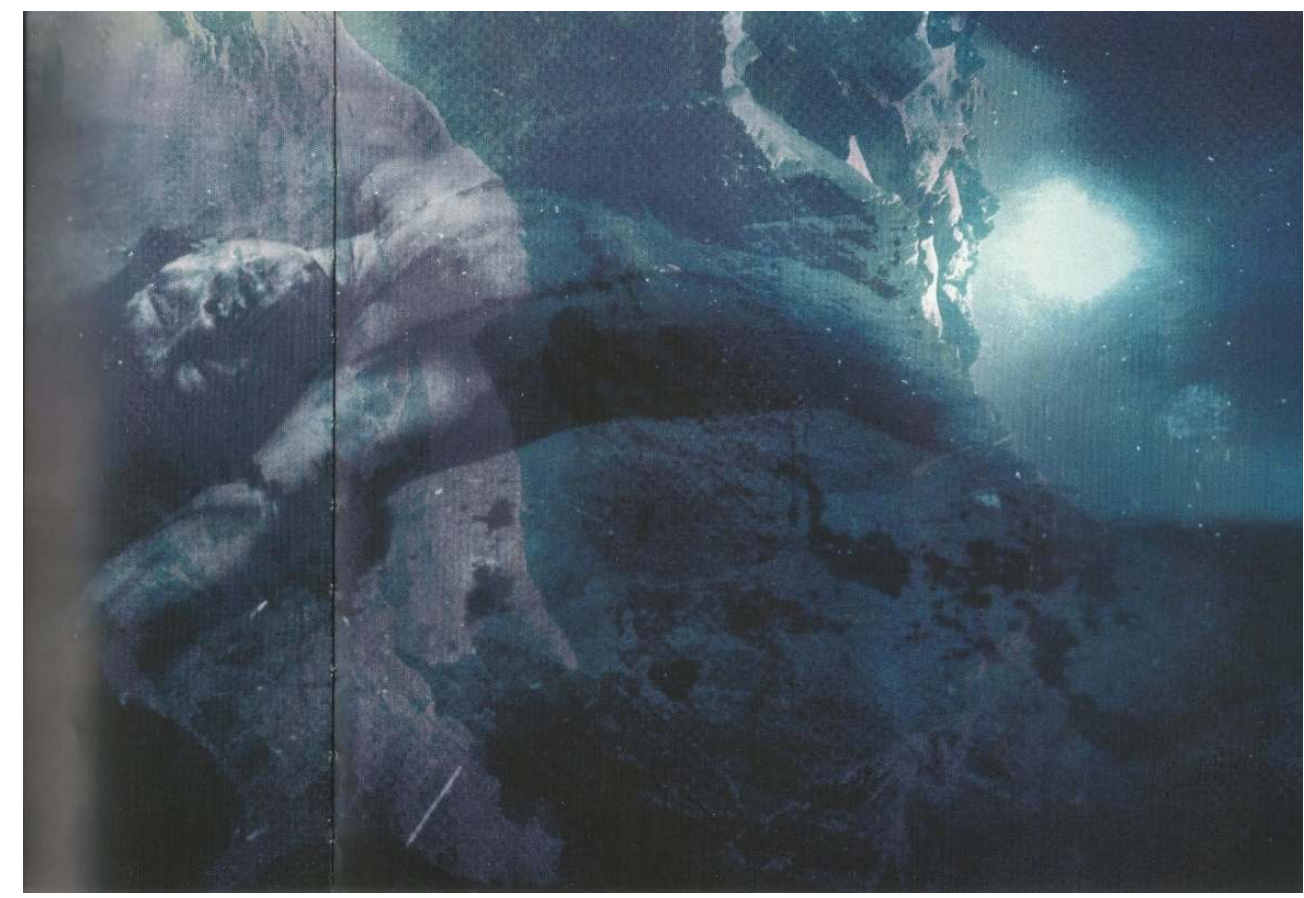

[Fig. 1] ANDUJAR, Claudia. Exxtase (1974-2003). Fotografia. In: ANDUJAR, Claudia. A vulnerabilidade do ser. São Paulo: Cosac Naify, Pinacoteca do Estado, 2005, p.196-197.

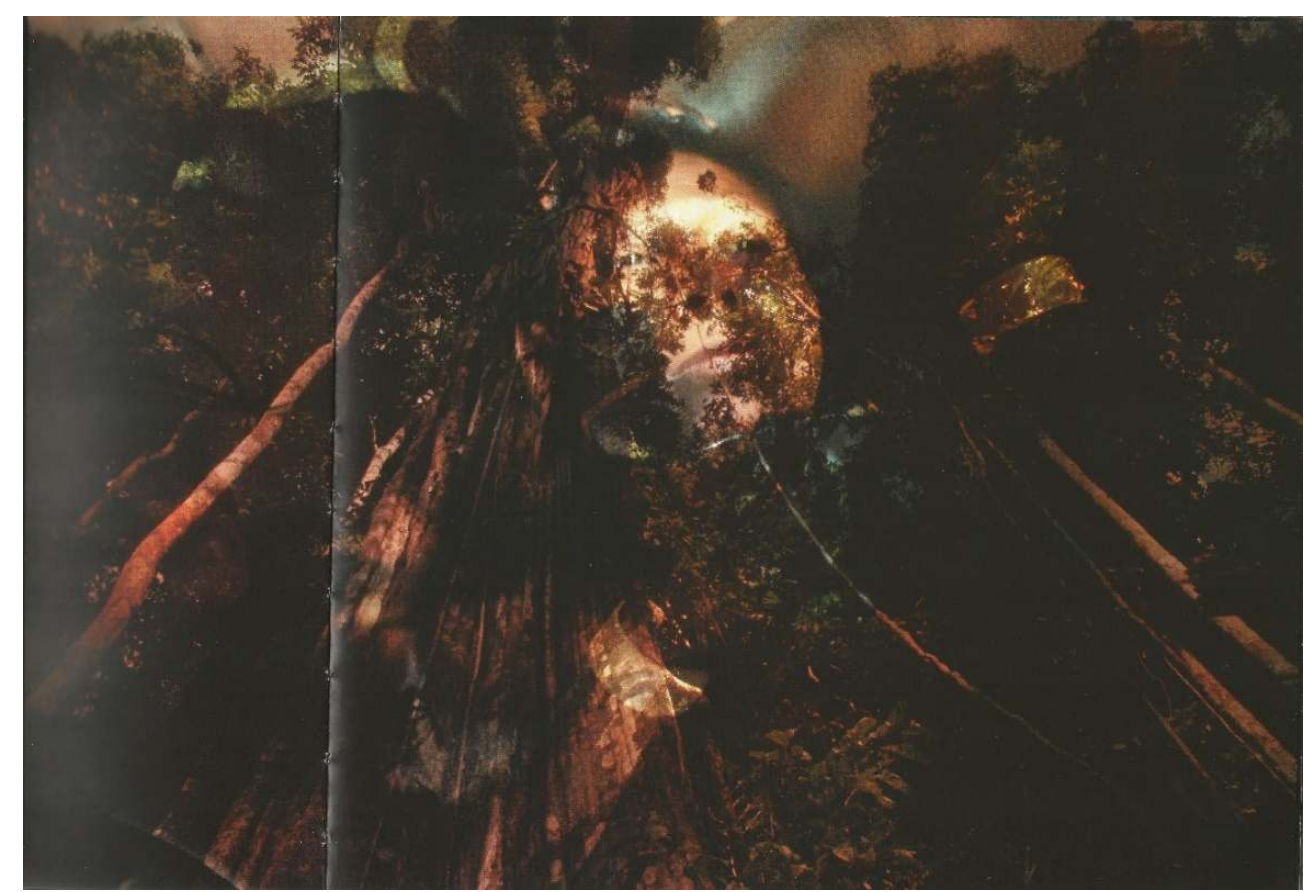

[Fig. 2] ANDUJAR, Claudia. Floresta Amazônica, Pará (1974-2003). Fotografia. In: ANDUJAR, Claudia. A vulnerabilidade do ser. São Paulo: Cosac Naify, Pinacoteca do Estado, 2005, p.186-187.

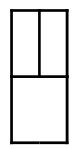



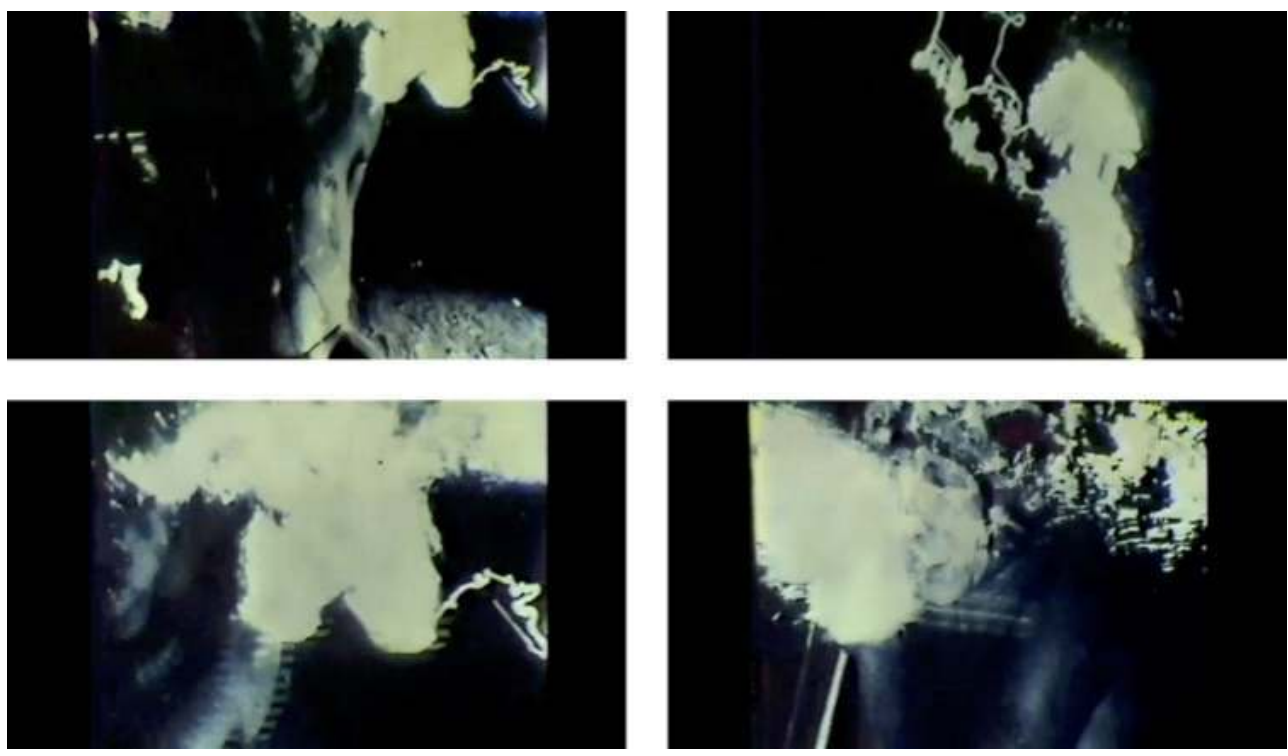

[FIg. 3] FRAMES do filme POVO dA LUA, POVO dO SANgUE (1985), DE MARCELLO TASSARA. DISPONÍVEL EM: <HTTPS://WWW.YOUTUBE.COM/WATCH?V=LACA3FZFCUY\&T=1383S>. ACESSO EM: 5 DEZ. 2017.

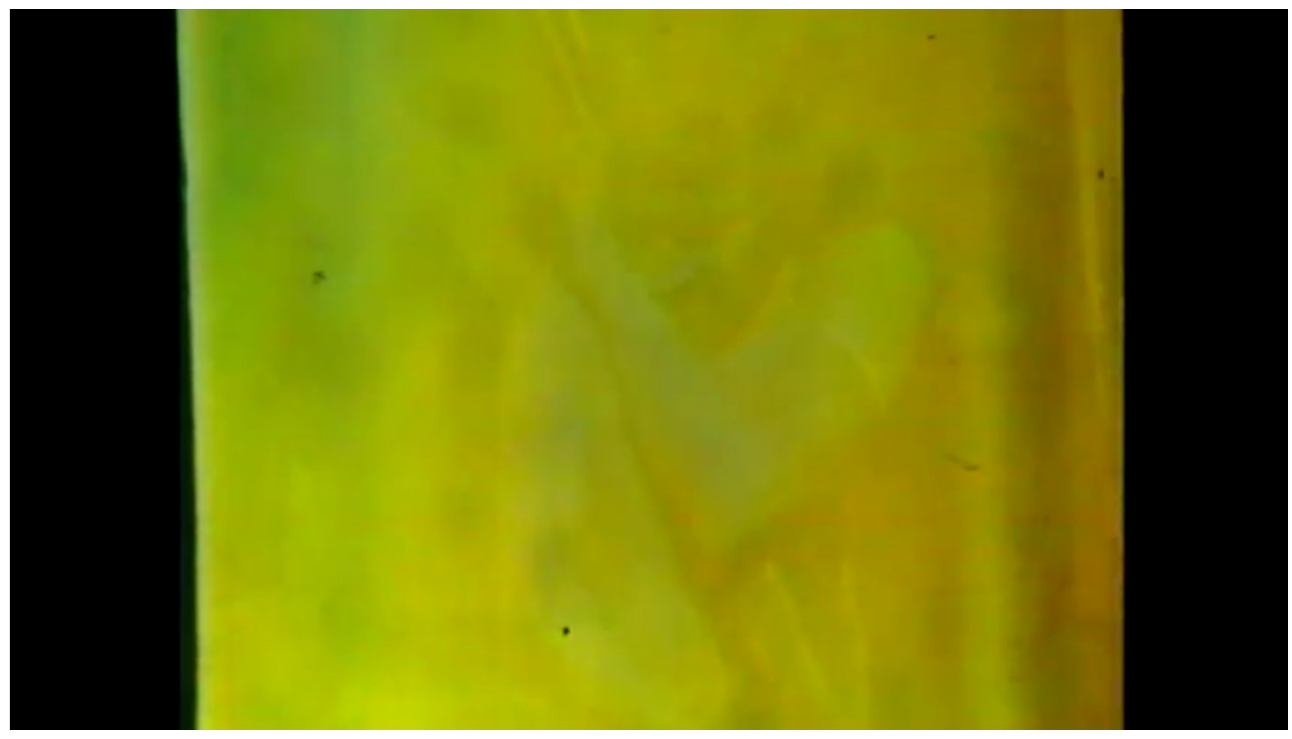

[Fig. 4] Frame do filme Povo da Lua, Povo do Sangue (1985), de Marcello Tassara. Disponível em: <https://www.youtube.com/watch?v=LACA3FzFCuY\&t=1383s>. Acesso em: 5 dez. 2017. 


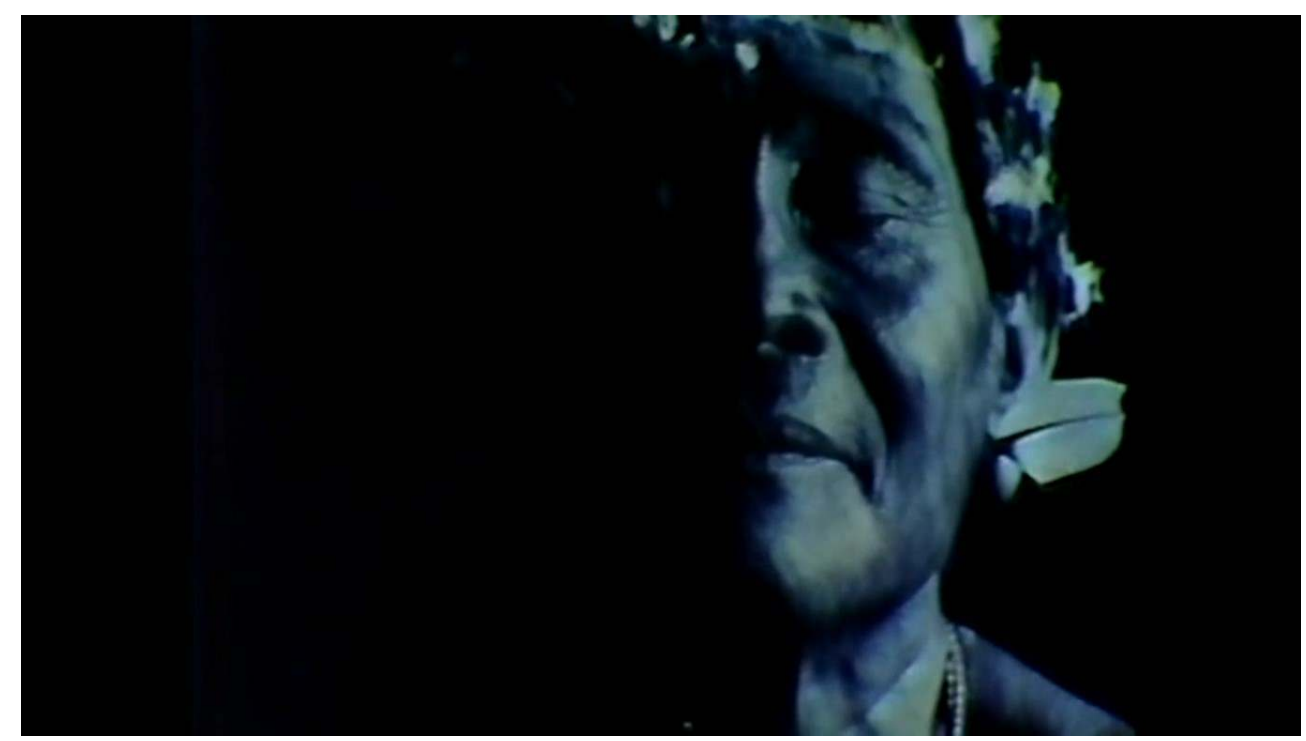

[Fig. 5] Frame do filme Povo da Lua, Povo do Sangue (1985), de Marcello Tassara. Disponível em: <https://www.youtube.com/watch?v=LACA3FzFCuY\&t=1383s>. Acesso em: 5 dez. 2017.

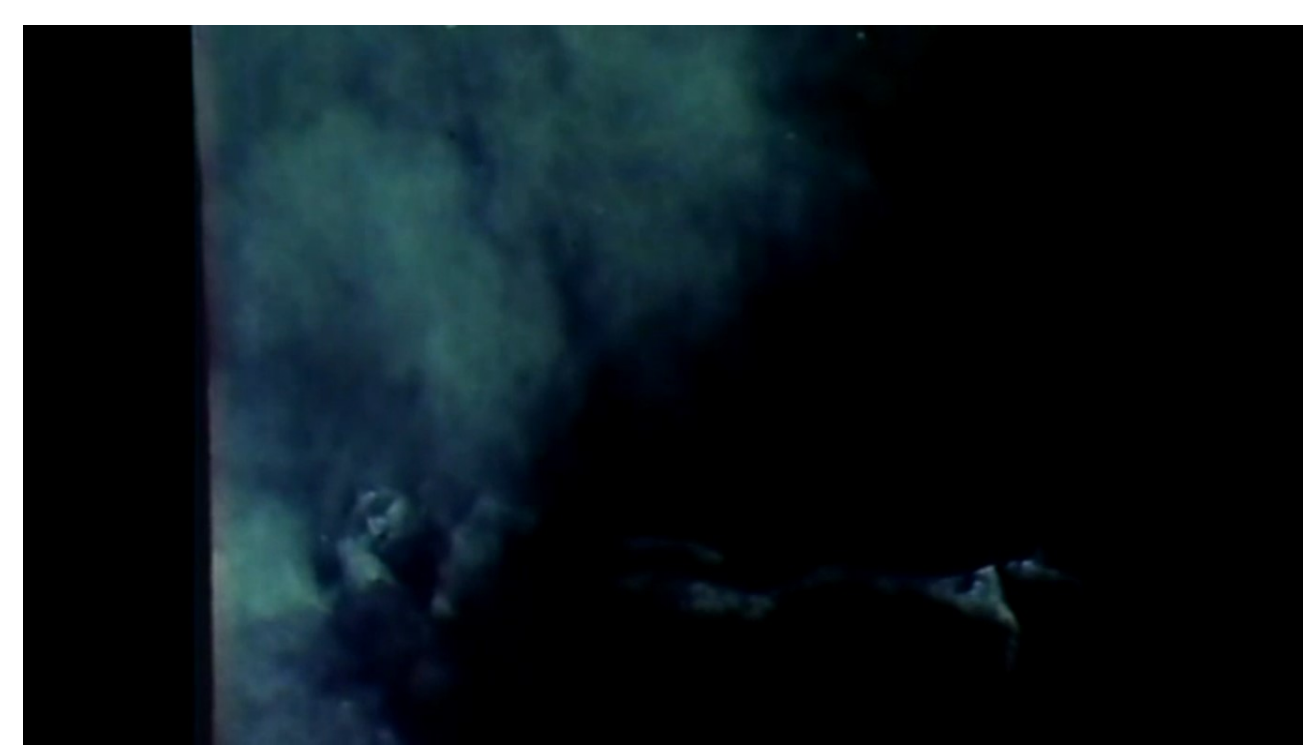

[Fig. 6] Frame do filme Povo da Lua, Povo do Sangue (1985), de Marcello Tassara.

Disponível em: <https://www.youtube.com/watch?v=LACA3FzFCuY\&t=1383s>. Acesso em: 5 dez. 2017.

\section{BIBLIOGRAFÍA}

ALBERT, Bruce. O ouro canibal e a queda do céu. Uma crítica xamânica da economia política da natureza (Yanomami). In: ALBERT, Bruce; RAMOS, Alcida Rita (Org.). Pacificando o branco: cosmologias do contato no norte-amazônico. São Paulo: Editora UNESP: Imprensa Oficial do Estado, 2002, p.239-274. 
ALBERT, Bruce. Prólogo. In: KOPENAWA, Davi; ALBERT, Bruce. A queda do céu: palavras de um xamã yanomami. Tradução de Beatriz Perrone-Moisés. São Paulo: Companhia das Letras, 2015, p.43-53.

ANDUJAR, Claudia. Mitopoemas Yanomami. São Paulo: Olivetti do Brasil, 1979.

ANDUJAR, Claudia. Yanomami: Claudia Andujar. São Paulo: Editora DBA, 1998.

ANDUJAR, Claudia. A vulnerabilidade do ser. São Paulo: Cosac Naify, Pinacoteca do Estado, 2005.

BRANDÃO, Eduardo; MACHADO, Álvaro. Ritual e reconstrução. In: ANDUJAR, Claudia. A

vulnerabilidade do ser. São Paulo: Cosac Naify, Pinacoteca do Estado, 2005, p.170-175.

DUBOIS, Philippe. Da imagem-traço à imagem-ficção: O movimento das teorias da fotografia de 1980 aos nossos dias. Discursos fotográficos, Londrina, v.13, n.22, jan./jul.2017, p.31-51. Disponível em: <http://www.uel.br/revistas/uel/index.php/discursosfotograficos/article/view/30295>. Acesso em: 16 out. 2017.

ELIAS, Érico. Da fotografia ao cinema: os fotofilmes de Marcello Tassara. Studium, n.29. 2009. Disponível em: <http://www.studium.iar.unicamp.br/29/6.html>. Acesso em: 1 nov. 2017.

HERKENHOFF, Paulo. A espessura da luz - fotografia brasileira contemporânea. In: ANDUJAR, Claudia. A vulnerabilidade do ser. São Paulo: Cosac Naify, Pinacoteca do Estado, 2005, p.228-237.

KOPENAWA, Davi; ALBERT, Bruce. A queda do céu: palavras de um xamã yanomami. Tradução de Beatriz Perrone-Moisés. São Paulo: Companhia das Letras, 2015.

MAUAD, Ana Maria. Imagens possíveis: fotografia e memória em Claudia Andujar. Revista Eco-Pós, Rio de Janeiro, v.15, n.1, 2012, p.124-146. Disponível em: <https://revistas.ufrj.br/index.php/ eco_pos/article/view/1196/1135>. Acesso em: 17 mar. 2017.

PEREIRA, Vera Lúcia. Marcados, de Claudia Andujar: do documento visual à imagem poética. 2015. 119 p. Dissertação (Mestrado em Artes). Instituto de Artes, Universidade Federal de Uberlândia. Uberlândia.

POVO da Lua, Povo do Sangue. Direção: Marcello Tassara. Fotografias: Claudia Andujar. 34 min, cor. Disponível em: <https://www.youtube.com/watch?v=LACA3FzFCuY\&t=1383s>. Acesso em: 5 dez. 2017.

VIVEIROS DE CASTRO, Eduardo. A floresta de cristal: notas sobre a ontologia dos espíritos amazônicos. Cadernos de campo, São Paulo, n. 14/15, 2006, p.319-338. Disponível em: <http:// www.revistas.usp.br/cadernosdecampo/article/view/50120/55708>. Acesso em: 4 jul. 2018.

Yanomami, l'esprit de la forêt. Toutes les expositions. Fondation Cartier pour l'art contemporain. Disponível em: <https://www.fondationcartier.com/\#/fr/art-contemporain/26/expositions/294/ toutes-les-expositions/606/yanomami-l-esprit-de-la-foret/>. Acesso em: 15 mar. 2017.

\section{NOTAS FINALES}

1. Segundo Érico Elias, fotofimes são filmes construídos a partir da técnica de "animação de fotografias", que, por sua vez, "consiste em partir de um material fotográfico para criar um filme (por isso, o nome fotofilme), dando vida às imagens não mais através da ilusão de movimento contínuo, mas com o uso de um tempo forçosamente artificial, cindido". (ELIAS, 2009).

2. Pensamos aqui na distinção entre "imagem-traço" e "imagem-ficção" que Philippe Dubois desenvolve em artigo recente publicado na revista Discursos fotográficos. (DUBOIS, 2017). 
3. Claudia aqui se refere aos desenhos realizados durante a pesquisa que culminou no livro Mitopoemas Yanomami, para o qual a fotógrafa solicitou a indivíduos da tribo, sobretudo xamãs, que elaborassem desenhos e textos reveladores de aspectos de seu universo sobrenatural, de modo a ajudar-nos em sua compreensão. (ANDUJAR, 1979).

4. Albert, estudioso da sociedade yanomami, participou, em 1978, da fundação da Comissão PróYanomami (CCPY), da qual Claudia Andujar foi coordenadora. Ao lado de Kopenawa, a comissão desenvolveu uma longa campanha em prol da homologação da Terra Indígena Yanomami, o que ocorreu em 1992, durante a Conferência das Nações Unidas sobre o Meio Ambiente e Desenvolvimento, no Rio de Janeiro (ECO-92 ou RIO-92).

5. Viveiros de Castro utiliza o termo xapiripë, em que pë seria o elemento pluralizador. (VIVEIROS DE CASTRO, 2006). Em A queda do céu, Kopenawa e Albert optam pelo termo xapiri, que, em si, já indicaria o plural, uma vez que tais espíritos andariam sempre em bando. (KOPENAWA; ALBERT, Op. cit.). Optamos, neste artigo, pela utilização do termo xapiri, conforme a segunda referência citada.

6. Tais imagens surgiram na década de 1980, quando Claudia Andujar, então coordenadora da CCPY, lutava pela demarcação de uma área territorial contínua suficiente às necessidades do povo yanomami, bem como pela implantação de um programa sistemático de saúde que promovesse a adequada imunização dos membros da tribo às doenças levadas pelo "homem branco". Com o programa aprovado pelo governo em 1980, Andujar pôs-se a fotografar cada indivíduo da tribo, marcado por um número de plástico que pendia em seu tórax à maneira de um colar, a fim de identificá-lo visualmente em sua ficha no Cadastro de Saúde Yanomami. (PEREIRA, 2015).

7. Segundo Elias, a narração em off é realizada por Marlui Miranda, que também se responsabiliza pela trilha sonora. (ELIAS, Op. cit.).

8. Muitas das fotografias mostradas nesse trecho do filme foram posteriormente publicadas no livro Yanomami: Claudia Andujar. (ANDUJAR, 1998).

9. Na narração em off, é utilizada a palavra "pajés". Aqui optamos por manter o termo "xamãs", que vem sendo empregado ao longo deste artigo, e não desvirtua o sentido proposto na narrativa fílmica, uma vez que os dois termos são utilizados para referir-se a indivíduos que desempenham papel social semelhante em tribos indígenas.

\section{RESÚMENES}

Este artigo propõe-se a analisar duas imagens da série Sonhos (1974-2003), de autoria de Claudia Andujar, fotógrafa suíça naturalizada brasileira, e um trecho do fotofilme Povo da Lua, Povo do Sangue (1985), do diretor brasileiro Marcello Tassara, que utiliza parte do acervo fotográfico de Andujar para criar uma narrativa em defesa do povo Yanomami. De um lado, o texto interroga-se sobre como, nas obras escolhidas, recursos fotográficos e cinematográficos são utilizados para exprimir aspectos do transe alucinógeno de indivíduos da tribo Yanomami, pela inalação da substância denominada yãkoana. De outro, busca significações para essas imagens a partir do modo de pensar yanomami, representado pelo testemunho do xamã Davi Kopenawa no livro $A$ queda do céu.

Cet article propose d'analyser deux images de la série Sonhos (1974-2003), réalisée par Claudia Andujar, photographe suisse naturalisée brésilienne, et un extrait du photofilm Povo da Lua, Povo do Sangue (1985) du réalisateur brésilien Marcello Tassara, qui utilise une partie de la collection photographique d'Andujar pour créer un récit en défense du peuple Yanomami. D'une part, le texte se demande comment, dans les œuvres choisies, des ressources photographiques et cinématographiques sont utilisées pour exprimer des aspects de la transe hallucinogène des 
individus de la tribu des Yanomami, par l'inhalation de la substance dénommée yãkoana. D'autre part, il cherche des significations pour ces images à partir de la façon de penser des Yanomami, représentée par le témoignage du chaman Davi Kopenawa dans le livre La chute du ciel

ÍNDICE

Mots-clés: Photographie; Cinéma; Transe; Yanomami; Claudia Andujar; Marcello Tassara

Palavras-chave: Fotografia; Cinema; Transe; Yanomami; Claudia Andujar; Marcello Tassara.

\section{AUTOR}

\section{ANA CAROLINA ALBUQUERQUE DE MORAES}

Doutoranda em Artes Visuais pelo Instituto de Artes da Universidade Estadual de Campinas. Professora do Departamento de Artes Visuais e Design da Universidade Federal de Sergipe. 